$\mathbb{T}$ periodica polytechnica

\author{
Transportation Engineering \\ $38 / 1(2010) 37,43$ \\ doi: 10.3311/pp.tr.2010-1.07 \\ web: http://www.pp.bme.hu/tr \\ (c) Periodica Polytechnica 2010
}

RESEARCH ARTICLE

\section{Methodology of transport regulation in the Slovak Republic}

\author{
Eva Nedeliaková / Anna Dolinayová / Jozef Gašparík
}

Received 2009-11-03

\begin{abstract}
This article deals with the analysis of the present state of transport regulation, the relevant legislation, the reasons behind regulations, its rules and tools, the charges to be paid for the usage of the railway infrastructure in the Slovak Republic as a subject of the regulations and problems of financing the investments in the railway infrastructure.
\end{abstract}

\author{
Keywords \\ regulation · transport policy $\cdot$ railway transport $\cdot$ railway in- \\ frastructure
}

\section{Acknowledgement}

This article is a part of research project VEGA no. 1/0411/08 Complex analysis and classification of tools for the regulation of transport in continuity with perspectives and calls of liberalising the transport market within EU.

\section{Eva Nedeliaková}

Department of Railway Transport, University of Žilina,, Univerzitná 8315/1, 010 26 Žilina,, Slovakia

e-mail: eva.nedeliakova@fpedas.uniza.sk

\section{Anna Dolinayová}

\section{Jozef Gašparík}

Department of Railway Transport, University of Žilina,, Univerzitná 8315/1, 010 26 Žilina,, Slovakia

\section{Introduction}

Nowadays the transport policy within the European Union aspires to harmonise and liberalise the market. European transport policy development is based on important changes. It is necessary to integrate these changes into the national transport policy in the Slovak Republic too. These elementary aims can only be successful in the case of equal economic competition.

The necessity of regulation results from economic drivers of transport, from the objective effect of the factors which lead to a deteriorated market environment and are inseparable from transport itself. The deformed market with negative influence to the environment and high social costs for transport are a result of these factors.

\section{The status quo}

The transport policy is a part of economic policy and also an instrument as induced by traffic needs on the required quality level. The conformity of transport policy aims is an essential precondition if the policy aims to become a dynamic component of economic development. Its goals also presume the connection of the traffic system in Slovak Republic to the integrated European traffic system.

The economic competition is one of the parts of transport policy which was born from aims and principles laid down by the Rome Convention which has played a dominant role ever since. The new conception of transport liberalisation was accepted during the period of creation of European Union and transformation of European Community. The political agreement about railway and combined transport support was created and also discussions were realized about tools definition, state support and regulation. It has become necessary to monitor the conditions and process of liberalisation. The monitoring covers technical and economic conditions and also the European traffic market development.

The interest of the Slovak Republic to participate in the international transport systems requires conforming to conditions that determine our participation in the traffic market. It also requires the complete implementation of the European Union's directives into our legal system. But the Slovak transport policy 
does not correlate well enough to the present development trends of the EU. There is not sufficient space for creating the applicable regulation environment in transport and for the adoption of legal norms in accordance with the EU standards.

\section{Legislation for transport regulation}

The economic competition, services in public interest and state support in the railway transport are subjects to general binding rule of law, which have been created to regulate inland transport.

Following regulations are the most important:

- Regulation (EEC) No 1017/68 of the Council of 19 July 1968 applying rules of competition to transport by rail, road and waterway, amended by Regulations No 1629/69, 1630/69, $1 / 2003$ and $773 / 2004$.

- Regulation (EEC) No 1191/69 of the Council of 26 June 1969 on action by Member States concerning the obligations inherent in the concept of a public service in transport by rail, road and inland waterway, amended by Regulations No 3572/90, No 1893/91, No 1370/07.

- Regulation (EEC) No 1107/70 of the Council of 4 June 1970 on the granting of aids for transport by rail, road and inland waterway, amended by Regulations No1473/78, No 1658/82, No 1100/89, No 3578/92, No 2255/96, No 543/97, No 1370/07.

Directly applied acts are among others the regulations and decisions about financial tools of the European Union - the cohesion fund and the structural funds - and legislation about the transEuropean network.

Besides these documents, the regulation and liberalization of the railway transport are adapted by directives, which are obligatory for member states.

Following directives are of a primary importance:

- Directive 2001/14/EC of the European Parliament and of the Council of 26 February 2001 on the allocation of railway infrastructure capacity and the levying of charges for the use of railway infrastructure and safety certification. This Directive replaces Directive 95/19/EC and covers infrastructure capacity allocation and charging.

- $1995 / 18$ on licensing of railway enterprises.

Both directives are considered to be executive act for transformation directive 1991/440 on the Development of the Community's Railway.

European Directive 91/440 marked the start of a change in the regulations governing rail organization. This Directive required an accounting separation between operation activities and infrastructure management activities and validated the European Commission's traditional approach which made a direct link between market openness and competitiveness.
The other Directives that followed (95/18, 95/19 and the recent Directives stemming from the 2001 Transport White Book (Directives 2001/12, 13 and 14 as well as Directives 2007/58, 2007/59) endeavored progressively to lay down the network access conditions and the measures to separate rail operation, infrastructure and management which resulted in the creation of competition between European networks for companies possessing the necessary licenses.

Concrete measures, concepts and forms for regulation of the railway transport are kept to state hands.

The Slovak Republic, as a member state of EU, must accept European legislation. The national legal act, which adopted European directives into railway transport, is Act No. 164/1996 on Railroads and on amendment to Trade Licensing Act No. 455/1991 as amended by Act No. 58/1997. Regulation of railway transport was secured through the last amendment of this act, also in the institutional framework, in accordance with the directives 14/2001 and 18/95.

\section{Regulation reasons - defaults of the market mecha- nism}

The most relevant situations when the state should interfere with the economic system of a given country or transport mode, are the following:

A. The competition is not perfect, therefore the market is not able to work effectively and it permits producer/provider to obtain dominant state above user.

Basic elements of perfect competition are as follows:

- existence of large number of providers and users,

- neither of them has such force as to be able to manipulate with the price, the company must accept the price which exists on the market, it is not in a position to change the price, therefore it is marked as price receiver,

- existence of equal conditions for all providers, who offer same products and services,

- liberty of entrance to the market and exit from the market,

- fully flexible demand.

Perfect competition is only a theory; it does not exist in practice. The market situation, when a provider can, with a certain measure, influence the price of his production on the market (as price creator), is defined as an imperfect competition.

Three forms of imperfect competition are well-known:

- monopolistic competition - the lowest rank of imperfect competition, large number of providers, each has his own offer, by means of offer he covers little part of the market, every company sells products or services partly different from similar product or service provided by competitive company, 
- oligopoly - few big companies exist in the sector, which share the command of the market, they have economic force, they defend entrance of other providers to transport sector, they put pressure on user to buy at higher prices,

- absolute monopoly - there is only one provider of services, who has a privileged economic position, he commands the whole market, he determines monopolistic high prices, no suitable substitutes exist and the provider is protected from the entrance of competitors to the market, he sells at higher prices than prices in conditions of perfect competition, he does not try to minimize production costs because there is a lack of competition pressure, he does not achieve maximum possible outputs, the volume of his production is little, it does not cover the demand.

\section{B. Externalities are created, the market is not able to work effectively.}

Externalities are side effects from production or consumption, which do not enter the market. They can be negative - damaging factors of production or consumption. They represent the creation of additional costs, which will not be covered and which were developed by activity of other subjects. A major problem is environmental pollution. It is a cause of detriment transfers costs associated with abolishment to the whole society. Main negative transport externalities are costs of infrastructure and congestions, traffic accidents, noise and air pollution [3].

Transport is the biggest power consuming sector. In the Slovak Republic power consumption grows mainly in road transport. It is caused by the increase in transportation output. Fig. 1 presents the comparison between the energy consumption of road and railway transport which is calculated in GJs.

Road transport uses up four times more energy on one kilometre than railway transport. Power consumption causes an environmental pollution and leads to climate change. In the Slovak Republic mainly those pollutants are monitored which have been produced by transport since 1990. Figs. 2 and 3 present the emission data for road and railway transport.

Emission results for road transport are in agreement with the CORINIAR method. This method is based on calculating the power consumption of different vehicles and their emission factors for different modes.

There are big differences between different vehicle categories. The biggest pollutant in the road transport segment is the individual passenger transport and the heavy vehicle transport. The pollutants of private cars are two times bigger per one passenger kilometre than that of the buses.

The assessment of the emissions of railway transport are based on the calculation of total power consumption and application of emission factors of diesel locomotives, diesel rail vehicles and mechanisation vehicles.

The annual emission in rail transport decreases because there is a reduced performance.
Positive externalities represent advantage or utility. They exist when the marginal social benefit of production and/or consumption exceeds the marginal private benefit, e. g. using of infrastructure by industry or citizen, lighting in the town).

Transport externalities are created, when user of transport:

- either does not pay the entire cost of his transport activity (including ecologic costs, congestions or accidents),

- or does not obtain absolute prosperity (infrastructure, costs).

Existence of externalities shows that the market is not able to solve all problems with production. State can influence them e.g. by support, it can spread positive externalities and eliminate the negative externalities.

C. The market is not able to provide the public good in the required volume

Public good involves activities which bring benefits for the society, and which which do not constitute the property of private enterprises. The continuing problem of public good with market operation is due to the market's inability to encourage production. Public good can hardly ever be effective, because it entails high costs and therefore it exceeds the possibilities of the private sector. It is assured by public sector [3].

Beyond these factors mentioned in points $\mathrm{A}, \mathrm{B}$ and $\mathrm{C}$, deteriorations of the market mechanism are also caused by discrimination on the employment market.

\section{Regulation rules and tools}

The definition of rules and tools for regulating transport including their consequences and effects on transport efficiency in accordance the legislative requirements of the Slovak Republic and the European Union is very important. It is one of the basic preconditions under which the trans-European transport system can effectively function in the immediate time horizon.

It is necessary to determine the positive and negative consequences of transport regulation tools and design suitable regulation tools and methods with regard to:

- supporting sustainable mobility by advanced public transport and environment-friendly and safe means of transport,

- applying market economy principles in the transport,

- viewing transport as an integrated transport system,

- harmonising the conditions in the transport market especially of the railway and road transport,

- the transport operation within the trans-European transport system.

The necessity of state intervention results from above mentioned defaults of the market mechanism. State creates the legal system, defines rules for economic competition, constructs financing rules and rules for safety as well as, technical specifications and a framework for social security. 


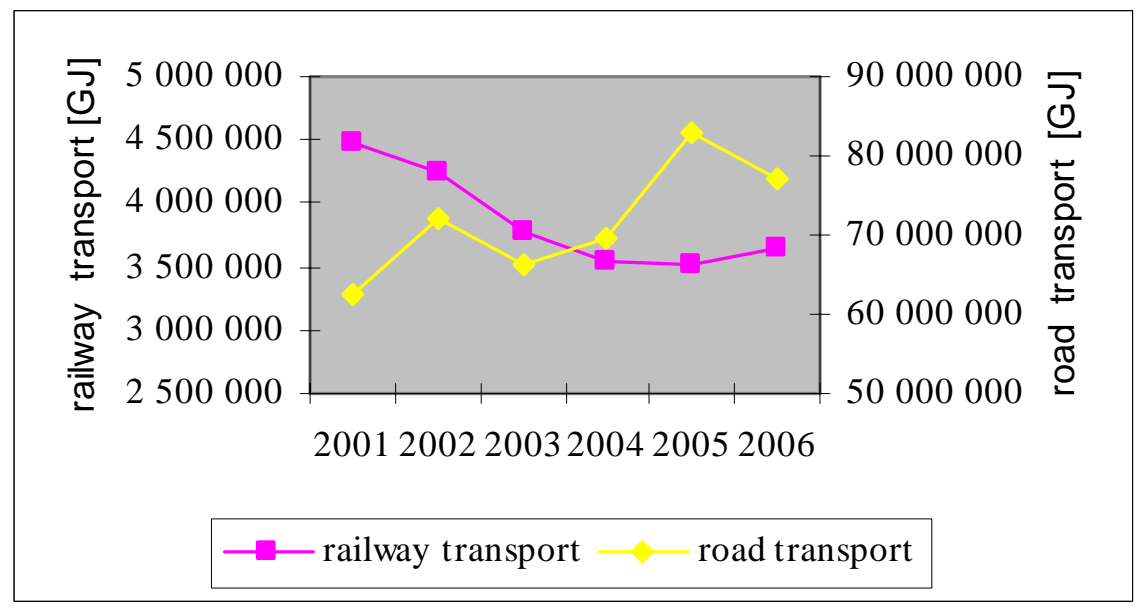

Fig. 1. Power consumption of road and railway transport in the Slovak Republic between $2001-2006$

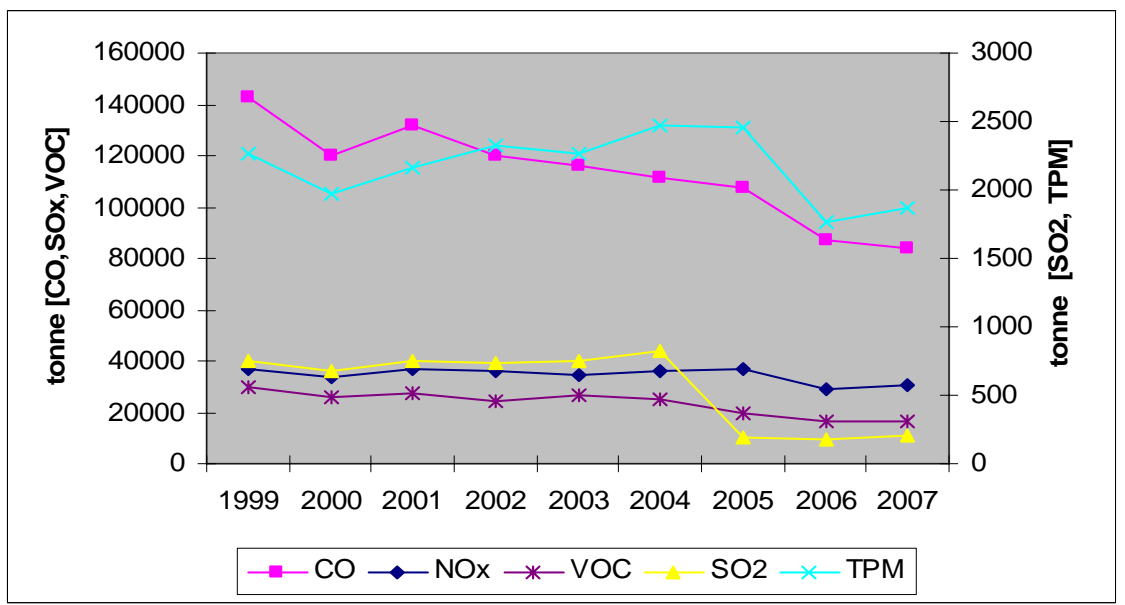

Fig. 2. Total emissions in road transport in the Slovak Republic in the period between 1999 - 2007

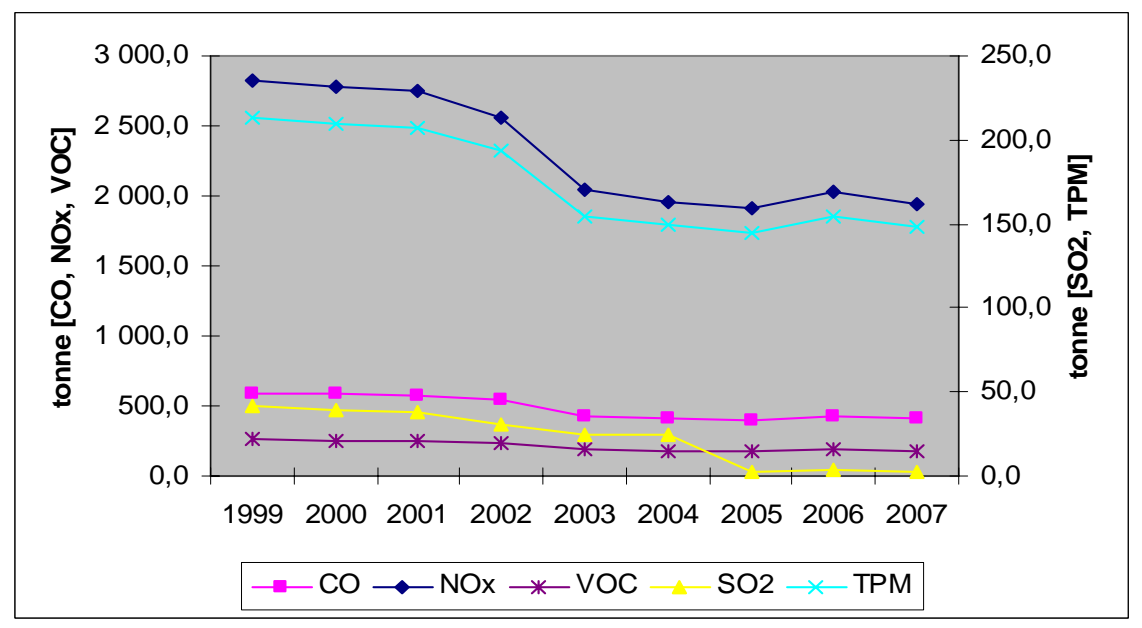

Fig. 3. Total emissions in railway transport in the Slovak Republic in the period between 1999 - 2007

The state assures the access to services and transport availability and takes up international responsibilities. Liberalization of transport, including railway transport, necessitated the change of regulation tools. Main regulation tools are the following: contract, order, common programs and grants for special purpose, price regulation in passenger transport, regulation of the charges to be paid for the use of the railway infrastructure, public competitions and independent regulators.
Serious liberalisation of railway transport sector should be based on the basic pillars of single market economy. Liberalisation should remain a respectable structure of relations and common rules of co-ordination and co-operation in the business. These common rules are very important for the effective operation of transport services and development of an integrated railway network. 


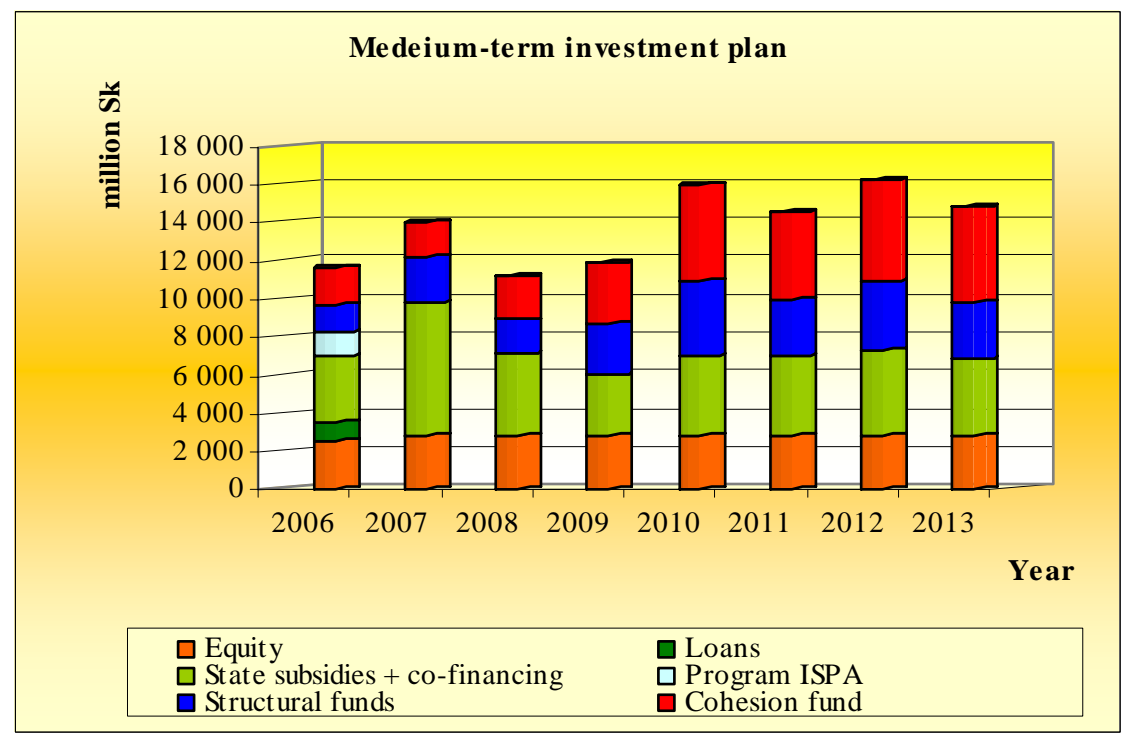

Fig. 4. Funds for financing the investments in the railway infrastructure in the period between 2006 - 2013 (million SK)

\section{Charge to be paid for the use of the railway infras- tructure as a subject to regulation}

Charges to be paid for the use of the railway infrastructure are in every European country subject to regulation. Generally, administratively set charges are not sufficient to cover total operation costs. For example in the Slovak Republic charges to be paid for the use of railway infrastructure allowed the infrastructure manager, The Railways of the Slovak Republic (ZSR), to cover only $71 \%$ of its total costs incurred in $2003,70 \%$ of the total costs in 2004, $66 \%$ of the total costs in 2005 and $67 \%$ of the total cots in 2006 [2].

It leads to a lack of funds for the investments in the railway infrastructure for the manager of the railway infrastructure. Lack of funds and lack of regulated charges result in fewer investments, contribute to a lower technical level of the infrastructure, to greater indebtedness of the manager and to lower competitiveness of rail services in the transport market.

The European Commission and European Parliament have decided to solve the problems of the lack of funds and unsatisfying technical level of the infrastructure through financial support granted to investments of European significance. The company's own resources make up only $20 \%$ of total planed investment expenditures in the period between 2006 - 2013. The rest is planned to be financed by the state budget and by European funds (see Fig. 47.

ŽSR (Železnice Slovenskej Republiky) was established by Act No. 258/1993 Coll. on the Railways of the Slovak Republic. As of January 1, 2002 ZSR was further divided into two independent entities according to the ŽSR Transformation and Reorganisation Project - into ŽSR and Železničná spoločnost', a.s. Railways of the Slovak Republic shall undertake activities related to the operation of railway infrastructure and the management of track transport and operability of railway tracks. The infrastructure manager provides transport services as well as other related activities in the line with the state transport policy and market demands. The main mission of ŽSR is as follows:

- management and operation of railway infrastructure,

- provision of operation-related services,

- founding and operating of railway, telecommunication and wireless networks,

- construction, regulation and maintenance of railway and funicular infrastructure,

- and other business activities as recorded in the Commercial Register.

Maximum prices for the use of railway infrastructure in domestic freight and passenger transport include the infrastructure costs related to the management and organisation of traffic on the infrastructure, operation of the infrastructure according to the Act on Railroads. Price for railway infrastructure is based on the decision of the Ministry of Finance of the Slovak Republic decision included in the list regulated price items. It states the maximum price applicable for all potential transport operators authorised to carry out their business on the territory of the Slovak Republic.

Type of train, track category, length of the train sections in transport operation and gross weight of the train are decisive factors in calculating the maximum price for the use of the railway infrastructure in domestic passenger and freight transport.

Current prices for using the railway infrastructure in freight transport are too high in Slovakia (see Fig. 6. On the other hand this price is global and includes not only the allocation of the train path but the other services, for example shunting as well.

At present the Authority for Railway Transport Regulation considers to change the calculation method of the price and the use of the railway infrastructure. There is an idea to create a 
Tab. 1. Sample of scheme for the weights and values of sub-indicators of a regulation in year...

\begin{tabular}{lllll}
\hline Sub-indicator & $\begin{array}{l}\text { Positive } \\
\text { trend* }\end{array}$ & Weight & Value/ level & Positivetrend achieved \\
\hline $\begin{array}{l}\text { Subsidies from } \\
\text { V/N }\end{array}$ & $0,1 / 0,2 / \ldots$ & value & Yes/No \\
for the budget & & & \\
ment of railway & & & \\
infrastructure & & & \\
\hline
\end{tabular}

*Positive trend from the view of the state, or the infrastructure manager or transport operators

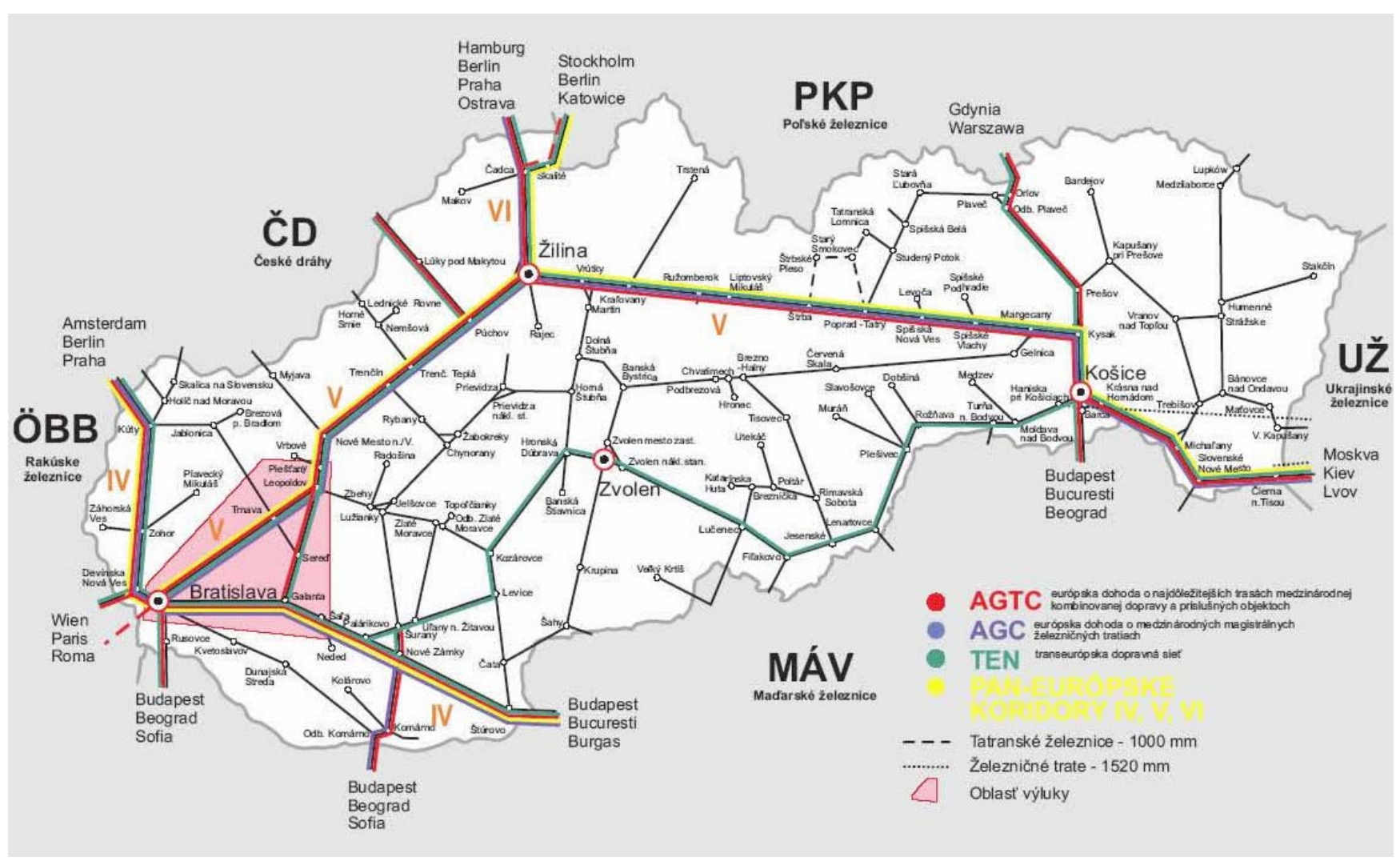

Fig. 5. Slovak railway infrastructure as a part of the pan - European corridors IV, V, VI, TEN-T network and AGC and AGTC agreement [2]

basic price packet including only the access to the infrastructure and every extra service would be charged separately (similar approach like in Hungary).

\section{Methodology for computation the regulation level}

To determine the impact of the various instruments of regulation of railway infrastructure, it is possible to use a comprehensive (complex) indicator of the impact of regulation, which is a combination of selected sub-indicators.

When constructing a similar indicator, we must take into account that in some sub-indicators - instruments of regulation, an increasing level of regulation is desirable whereas in case of other sub-indicators a decreasing level of regulation is required. The following formula can be used to calculate the complex indicator of the impact of regulation $-\mathrm{U}_{R}$ :

$$
U_{R}=\sum_{v=1}^{V} w_{R V} \times U_{R V}+\sum_{n=1}^{N} w_{R N} \times \frac{1}{U_{R N}}
$$

where:

$\mathrm{V}$ - The number of sub-indicators, which has a positive trend with increasing value.

$\mathrm{U}_{R V}$ - The value of the V-th sub-indicator of this kind.

$\mathrm{N}$ - The number of partial indicators, which is a positive trend with decreasing value.

$\mathrm{U}_{R N}$ - The value of N-th sub-indicator of this kind.

$\mathrm{w}_{R V}, \mathrm{w}_{R N}$ - The weight of sub-indicators, where the following must apply:

$$
\sum_{v=1}^{V} w_{R V}+\sum_{n=1}^{N} w_{R N}=1
$$

The weights and values of sub-indicators can be entered in the form of Table 1 . For specific regulatory instruments it is necessary to determine their individual weihts. The method of how to apply this complex indicator of the impact of regulation is currently being designed in research in the Department of Railway Transport. 


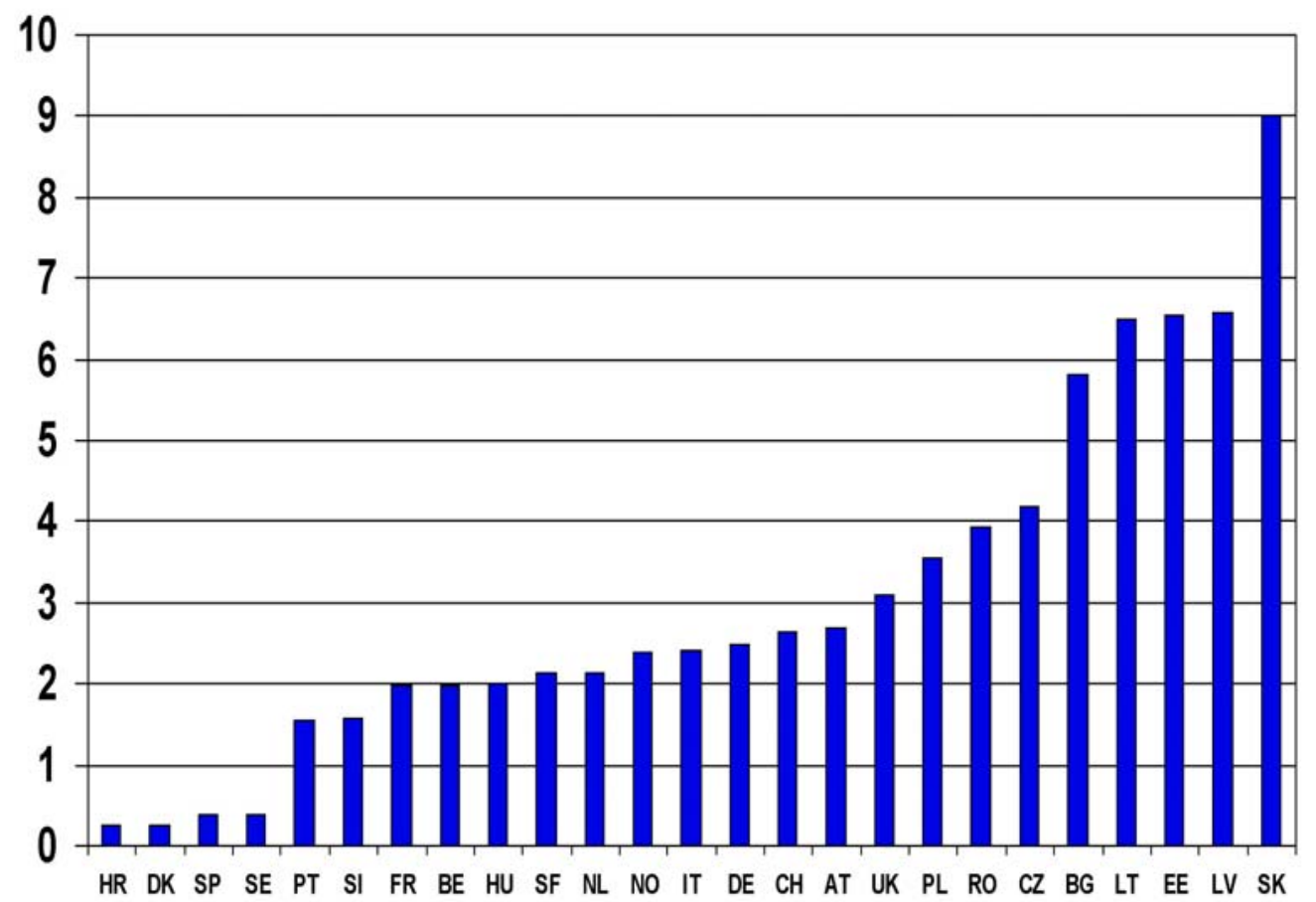

Fig. 6. Infrastructure charges ŽSR - a typical freight train 960 tonnes (train km)

\section{Conclusion}

The liberalised transport market requires the existence of a modern traffic system which enables large trade traffic output and a simultaneously high activity of the transport sector. The main problem in the management of railway infrastructures in the Slovak Republic is the inadequateness of the charging principles. The absence of market prices in the railway transport has a negative effect in the market of transport services. It deforms the relative prices of individual services and thus generates unbalance among the modes of transport. The road transport market share is higher in comparison with other modes of transport. This fact leads to the overcharging of road infrastructure, increases risk and accident rate and pollutes the environment.

The European Commission addresses this situation by different regulations. These regulations increase costs and prices of road operators indirectly so that this should increase the attractiveness of other modes of transport.

Transport regulation problems are large and significant and their solutions are divided between different methods. The regulation of transport is an objective demand and it plays a key role in the implementation of the transport policy of the European Union.

\section{References}

1 Directive 2001/14/EC of the European Parliament and of the Council of 26 February 2001 on the allocation of railway infrastructure capacity and the levying of charges for the use of railway infrastructure and safety certification.

2 Internal sources of the Railways of the Slovak Republic, year 2007.

3 Kopicki R, Thomson S L, Best Methods of Railway Restructuring and Privatization, available at wWw . worldbank. org the World Bank.

4 Kendra M, Voleský K, Valovič R, The instruments of rationalization in railway freight transport, Transport of 21 st century, international scientific conference, Politechnika Warszawska 2007.

5 Nedeliaková E, Hrivnák M, The consequences of price regulation for the use railway infrastructure, Railway market, Central and Eastern European Review 2/II (2007), 33-37.

6 , Negative consequences of price regulation for the use railway Infrastructure 2 (2007), no. 7-8, 44-46. (in Slovak) Doprava a logistika.

7 Regulation (EEC) No 1191/69 of the Council of 26 June 1969 on action by Member States concerning the obligations inherent in the concept of a public service in transport by rail, road and inland waterway. 